them with Reticuloceras reticulatum mut. $\beta$, a fossil which is characteristic of an horizon near the Third Grit in Lancashire. This identification agrees specifically with the original identification by the Survey palaeontologists. Any doubt there may be regarding the significance of the break between the Millstone Grit and the Carboniferous limestone is set at rest by the relations of the two formations at this locality. The fossils obtained from the limestone indicate, it is believed, the lower part of the Seminula zone (S1) and the rest of the Main limestone, which attains a thickness of about 600 feet at Pendine, some miles to the east and a much greater thickness farther south, is missing owing to overstep at the base of the Millstone Grit. The horizon of the above-named goniatite in Lancashire is several thousands of feet above the base of the Upper Carboniferous (Lancastrian of Bisat). In the Haverfordwest Memoir (p. 151) the suggestion is made that there is overlap at the base of the grit since the shale bands near Haverfordwest appear to correspond with bands that are underlain farther east by a considerable thickness of shales and quartzites that are not represented in the western area. Definite evidence in support of this suggestion can only be obtained by the collection of fossils from the shales in the Eastern districts.

The Untvergity,

O. T. Jones.

MANCHESTER.

\title{
THE TECTONICS OF THE SOUTHERN MIDLANDS.
}

SIR,-I have read with much interest the paper on the "Structure of the Southern Midlands," appearing in your July issue. Attention is there drawn to a probable axis of unrest running south-eastwards from Nuneaton which, it is suggested, may account for the sudden disappearance of the Lower Greensand at Leighton Buzzard. I write to call attention to further evidence bearing on the existence of this axis. The line indicated above, if continued to the south-east, enters the Tertiary outcrop in north-west Middlesex, in the PinnerWatford area. It is a significant fact that the Reading Beds are exceptionally thin and sandy in this region, while they thicken both north-eastwards and south-westwards, resuming at the same time their normal lithology. Nearer London there is evidence that the same axis was active in Thanetian times, for the Thanet Sands are thin and locally absent over a limited tract in north-west London. It is also of interest to note that the London Clay thins westward against this axis, but thickens again on the further side towards the Bagshot country. The full evidence for these statements cannot be given here, but it is hoped that it will soon be published.

It may be thought by some a far cry from London or Watford to Nuneaton, but there can be no doubt that posthumous movements along severalCharnian lines materially affected Eocene sedimentation. One need only refer to the case of the Ipswich axis so fully worked 
out by Professor Boswell. Further, when it is remembered that the Palaeozoic floor is at comparatively small depth beneath the London Basin, it seems natural, if not inevitable, that the thin Neozoic cover should accommodate itself in detail to the structure of the thicker and more rigid underlying mass.

S. W. WOOLDRIDGE.

\section{ANNOUNCEMENTS AND INQUIRIES.}

The late Professor Charles Lapworth and Dr. T. Stacey Wilson were engaged for many years in mapping, on the 6-inch and 25-inch scales, the Cambrian rocks of the Harlech dome. Their work was unfinished at the time of Professor Isapworth's death, and Dr. Wilson finds that he has not sufficient leisure to complete the work himself. In these circumstances Professor W. S. Boulton, who has the custody of Professor Lapworth's field-maps, has, with Dr. Stacey Wilson's approval, invited Dr. C. A. Matley, a former student of Professor Lapworth, to continue the survey of the area and to put the results into a form suitable for publication. Dr. Matley has consented to do this, and will take up the work next summer after completion of his own work in South-Western Lleyn. 